\title{
Criminal Law, Civil Order and Public Wrongs*
}

\author{
R. A. DUFF \\ University of Stirling
}

\begin{abstract}
This is a response to five critiques of my 2018 book The Realm of Criminal Law, by Michelle Dempsey, Kimberley Brownlee, Roberto Gargarella, Tatjana Hörnle, and Gustavo Beade. Topics covered include the idea of a "public wrong"; the usefulness of the analogy I draw between criminal law and codes of professional ethics; how criminal law can function in polities characterized by deep cultural and normative differences; what scope there is for thick principles of criminalization; and whether offenders have a "right to be prosecuted".
\end{abstract}

Keywords: pCriminal law, public wrongs, professional ethics, multiculturalism, principles of criminalization, criminal trials, a right to be prosecuted.

\section{INTRODUCTION}

I would like to thank the other contributors to this symposium for their critically constructive responses to my book (Duff 2018): I cannot do justice to all their comments here, but will tackle (what I take to be) their most significant criticisms. They certainly expose some of the ways in which I failed to make my claims and arguments clear enough (to myself as well as to others), and they bring out some of the ways in which the book's central themes need to be further developed; but I hope to show that they do not threaten the central ideas that I tried to explain and defend. In what follows I first give a brief account of the book's aims and main themes (s. 2), and then respond to each of the commentators: to Michelle Dempsey, who

* I am very grateful to José Luis Martí, Roberto Gargarella, and Gustavo Beade for arranging and editing this symposium, and for organizing the workshop at Universitat Pompeu Fabra at which drafts of the papers were discussed; and to the participants in that most enjoyable workshop. 
offers an alternative account of the central idea of public wrongs (s. 3); to Kimberley Brownlee, who criticizes the use that I make of an analogy between criminal law and codes of professional ethics (s. 4); to Roberto Gargarella, who argues that my account of public wrongs cannot be sustained in the context of radically plural societies (s. 5); to Tatjana Hörnle, who argues that we should replace my single, thin, principle of criminalization by a more pluralist account grounded in three distinct principles (s. 6); and to Gustavo Beade, who develops the suggestion that public wrongdoers have a "right to be prosecuted" (s. 7).

\section{THE REALM OF CRIMINAL LAW}

The book emerged from a four-year research project on Criminalization, on which I worked with four colleagues: Lindsay Farmer, Sandra Marshall, Massimo Renzo, and Victor Tadros. The purpose of the project was, as we rashly described it, "to develop a normative theory of criminalization: an account of the principles and values that should guide decisions about what to criminalize", and that was also my goal when I started work on the book. In one way, the book achieved that aim, since it offers a "public wrongs" theory of criminalization, whose central principle is:

A. We have reason to criminalize a type of conduct if, and only if, it constitutes a public wrong.

B. A type of conduct constitutes a public wrong if, and only if, it violates the polity's civil order. ${ }^{2}$

In two ways, however, this will disappoint those looking for a developed, substantive theory of criminalization. First, the principle is extremely thin, since it leaves most of the substantive work, in determining just what kinds of conduct we have good reason to criminalize, still to be done. For until we have given content to the ideas of "civil order" and "public wrongs", which is itself a major normative undertaking, we cannot begin to work out this theory's implications; and even when we have given those ideas substantive content, we will have worked out only what we have reason to criminalize, not what we should criminalize, all things considered. Second, most of the book is taken up, not with exploring the implications of this

1 See Duff et al (2014: 1), which describes the project, and the other publications that it produced-and explains why it did not produce such a theory. I should record here my enormous debt to my colleagues on the project, as well as to the UK Arts and Humanities Research Council, which funded the project.

2 This principle is formulated in Duff (2018: 232, 275, 277), and explained in chs 6-7 of the book. 
principle, but with more preliminary discussions of the way in which, the grounds from which, we can arrive at this master principle of criminalization. I can best explain the aims of the book by responding to these two grounds for disappointment.

If we are to decide what kinds of conduct we have reason to criminalize, we must ask what counts as a reason to criminalize; to decide that, we must ask what the purpose of criminalization could be, which is to ask what the purpose of criminal law could be. To answer that question, we must examine the role that criminal law can play within the institutional framework of a political community: for criminal law is, and must therefore be theorized as, part of the political structure of a polity. ${ }^{3}$ If we are to tackle that task, however, we must first have some idea of what criminal law iswhat distinguishes it, as a particular kind of institutional practice, from other institutions? Accordingly, the book begins with an account of criminal law as a practice that defines a set of wrongs whose perpetrators (actual or alleged) are to be called to formal public account through a criminal process, and to be formally censured, and liable to punishment, if proved guilty. This is not intended to be a neutral analysis of "the concept of criminal law": rather, it offers a rational reconstruction of criminal law as an institution with a distinctive character, of which we can usefully ask what role (if any) it should play in a political community. Theorists of criminal law often focus on criminal punishment as its central characteristic, or as the end point towards which the substantive criminal law and the criminal process are directed: by contrast, I suggest that whilst criminal punishment is indeed a salient, and normatively problematic, feature of our systems of criminal law, a plausible justificatory rational reconstruction of criminal law need not, and should not, make punishment thus central; we can identify purposes and values in the criminal law that do not depend on punishment.

The claim that criminal law is essentially concerned with wrongs obviously implicates some version of legal moralism. Chapter 2 therefore discusses different species of legal moralism. It provides a defense of "negative legal moralism" - the claim that we may not criminalize conduct that is not morally wrongful prior to its criminalization; it distinguishes the version of "positive legal moralism" that I defend, according to which only "public" wrongs can give us reason to criminalize, from more familiar, more ambitious, versions, according to which we have reason to criminalize

3 My focus in the book is almost entirely on the domestic criminal law of nation states (though I say a little about international criminal law in ch. 3.1-2): whatever the future of the nation state might be, this is the context in which criminal law is most fully developed. 
every type of morally wrongful conduct; ${ }^{4}$ and it provides an initial explanation of the idea of a "public" wrong by discussing the codes of ethics that professional bodies draw up-codes that identify the kinds of wrong that count as "public" for the profession in the sense that they fall within the profession's distinctive practice. There is, I argue, a useful analogy between the criminal law, as the code of a political community, and a code of professional ethics: from which it follows that an account of public wrongs in relation to criminal law must depend on an account of the public realm of the polity. Those drawing up a code of medical ethics must begin with a conception of what medicine is as a distinctive practicewhat kinds of activity medicine involves, what aims and values should guide those activities: only then can they work out what kinds of conduct fall within its scope, and then what kinds of conduct must count as wrongs that concern the medical profession-as wrongs that count in that context as "public" wrongs. So too, if we are to draft a criminal code, and decide what kinds of conduct it ought to cover, we must begin with an account of the distinctive kind of practice whose code this is to be, of the aims and values by which that practice is (supposed to be) structured, and of the kinds of conduct that fall within its scope. That practice is the practice of civic life-the practice of living together as members of a political community: the "public" realm, the realm within which criminal law operates and within which we can identify the kinds of public wrong with which criminal law is concerned, is the realm of civic life. If we are to work towards a theory of criminalization, we must therefore begin with an account of the distinctive practice of civic life: only then can we work out what kinds of conduct could count, from the perspective of the polity and its criminal law, as "public" wrongs.

Chapter 3 embarks on this task by looking first at the identity of those who participate in the practice of civic life-those whose law the criminal law is supposed to be. It argues that citizens, as members of the polity whose law it is, are the criminal law's primary addressees: it is to them that the law paradigmatically speaks, in terms of values that are meant to be their values; it is to their fellow citizens that they must answer for the public wrongs they commit; and in democratic polities it is they who "own" the criminal law-it is their law. Questions must then arise: about the relationship between the domestic criminal laws of nation states, as the laws of their citizens, and international and transnational criminal law (questions discussed only briefly in this book); and about the status of those who are not citizens of the polity but are still supposedly bound by its

4 Michael Moore is the best known contemporary proponent of this more ambitious kind of legal moralism: see e.g. Moore 1997: chs 1, 16, 18. 
law, or of those who dissent from the polity's values as reflected in its criminal law (questions that I discuss in more detail, to show how an account that, like mine, makes citizenship central can still do justice to non-citizens, who are to be treated as guests, and to dissenters).

Chapters 4-5 then provide an account of the kind of practice in which citizens are engaged: the "public realm" that constitutes their life together as citizens, in which criminal law operates as a type of public law. ${ }^{5}$ The concept of "civil order" is central to an understanding of this public realm (see Farmer 2016): a polity's civil order consists in the normative ordering of its civic life - of its existence as a polity. That normative ordering is structured by the set of goals and values through which the polity constitutes itself as a political community: it can be partly defined in a written constitution, as a formal statement of the fundamental goals towards which the polity's collective activities are oriented, and the values by which those activities are to be governed; but it is also implicit in the polity's institutions of government and its citizens' shared understandings of their civic life. Such a conception of civil order, as the ordering of the polity's public realm, depends on a normative distinction between "public" and "private" realms: a polity's civil order constitutes its public realm, in relation to which other aspects of its citizens' lives are "private"; we must therefore attend to different distinctions between "public" and "private" that can be drawn. We must also attend to the preconditions of civil order: what kinds of agreement, what kinds of shared understanding, among the citizens are necessary if civil order is to be possible, and what can those who share such understandings say to those who do not? But given a viable conception of a polity's civil order, and thus of its public realm, we can make better sense of the idea of a public wrong, as a kind of wrong that falls within that public realm, and that violates that civil order: such wrongs are in principle the business of the polity's criminal law, as wrongs to which a formal, public response is appropriate (or even necessary).

Chapter 5 puts more substantial flesh on the relatively formal account of civil order provided in Chapter 4, by sketching the central aspects of the civil order of a particular kind of polity-a liberal republic of free and equal citizens: it draws on the republican tradition of political thought (and on a liberal kind of communitarianism, or communitarian kind of liberalism) to portray the kind of polity that we can plausibly aspire to create. We can then see the role that criminal law could play in such a polity as helping to sustain, but also as partly constituting, its civil order. For once we

5 The slogan that criminal law is public law has become prominent recently, as part of the reaction against what its proponents see as unduly moralised conceptions of criminal law: see e.g. Thorburn 2010, Chiao 2019. 
understand the idea of a public wrong, as a wrong that violates an aspect of civil order, we can see criminal law as an appropriate way of marking, and responding to, such wrongs. Its central role is to declare some of the central norms of that civil order, as norms that define what kinds of conduct citizens are entitled to expect from each other (and from the polity); and then to provide the process through which those who are accused of violating these norms can be called to formal, public account by their fellow citizens: in doing so, it gives institutional form to the polity's commitment to its defining values, and to its appropriately respectful concern for all its citizens-including both victims and offenders. (To say that the criminal law's central role is to declare such norms and to provide for those who violate them to be called to public account is to deny that punishment is the primary purpose of criminal law: but given the oppressive salience of punishment in our existing systems of law, I also say something about the role of punishment in a liberal republic's criminal law.)

Given this account of the role of criminal law in the civic life of a democratic republic, I turn, in Chapter 6, to criminalization: in particular, to the question of whether a normative theory of criminalization should offer a "master principle" by which our deliberations about criminalization could be guided. Different kinds of master principle are distinguished; some familiar master principles (notably the harm principles) are critically discussed. One central conclusion is that any plausible master principle will be very thin: it will provide, that is, not substantive criteria for criminalization, but formal criteria that leave most of the substantive normative work in deciding what kinds of conduct are to be criminalized still to be done. This is true of the master principle that emerges in the book: we have good reason to criminalize a type of conduct if and only it constitutes a public wrong; ${ }^{6}$ and it constitutes a public wrong if and only if it violates the polity's civil order. This principle is very thin, in that it leaves the normative questions of how the polity's civil order is to be constituted, and of what kinds of conduct should be taken to constitute violations of that order, still to be decided (through the process of public deliberation by which a democratic republic forms its criminal law). But we should not expect to be able to identify a master principle that is both thick and plausible; and the thin principle that I propose is still fruitful in identifying thekinds of consideration that are relevant to debates aboutcriminalization, and thus in showing how deliberations about criminalization ought to be structured-what kinds of claim and argument must be made and

6 The most a master principle can plausibly offer is an account of what gives us good reason to criminalize, not of what we should criminalize all things considered. 
defended if we are to be justified in criminalizing a type of conduct.

Chapter 7 seeks to make good on that claim for a "public wrongs" master principle, but only after an essential qualification. Criminalization is just one among a range of possible responses to public wrongs, distinguished from other responses by its concentration on the wrongfulness of the criminalized conduct and on calling perpetrators to public, censorial account. So the question whether we have good reason to criminalize a type of conduct is the question whether we have good reason to criminalize it rather than to respond in some other way; and a master principle of criminalization must help us to make that kind of "rather than" decision. To illustrate the work that the "public wrongs" principle can do, I briefly discuss examples of three kinds of criminal offence. First, I discuss "mala in se", consisting in conduct that is held to be wrongful prior to its legal regulation. These are in one way the most straightforward kinds of crime to understand, but are in two respects somewhat complicated: for the criminalization process is a process not simply of trying to capture some pre-existing moral wrong, but of constructing a civic conception of the wrong as a public wrong; and, partly for this reason, the distinction between "mala in se" and "mala prohibita" (the latter being understood to consist in conduct that might be wrongful only because it is legally prohibited), whilst still important, is less clear cut than many think it is (or should be). Second, I discuss different species of "malum prohibitum", involving different ways in which violations of pre-criminal legal regulations can constitute criminalizable wrongs: the distinction between regulation and criminalization is important here, as are the different ways in which regulatory violations can be wrongful (even when the conduct does not cause the kind of mischief at which the law is aimed). Third, I discuss examples of "pre-emptive" offences, which criminalize conduct that does not itself involve the mischief at which the law is ultimately aimed, but is in some way preparatory to, or increases the risk of, that mischief: one way in which our criminal laws have been expanding, especially in relation to terrorism, has been in the creation of wider kinds of pre-emptive offence; it is important to see how far such offences can be justified.

These discussions of different kinds of criminal offence are intended to be illustrative, rather than exhaustive: they illustrate the kinds of argument and deliberation that will be needed if we take a "public wrongs" principle, of the kind I have argued for, as our guide to criminalization. Those arguments and deliberations will have different contents in different polities, reflecting as they will different conceptions of a polity's civil order, and I have not tried to argue in this book for one particular such conception: 
which is not to say, as we will see, that I advocate a radical relativism according to which a polity's conception of its own civil order, and the criminal laws that it creates to sustain that order, are beyond criticism or argument; but such criticisms require an engagement with substantive political theory that goes beyond the scope of this book. I have indicated the kind of (republican, liberally communitarian) political theory that I favor, and I have sketched some of its implications for civil order and for the criminal law; but I have not tried to justify, or indeed to explicate in detail, that theory, or to defend it against others - that would be a task for another book (and this book was already long enough, if not too long).

I turn now to engage with my commentators and to respond, if not to all their suggestions and criticisms, at least to the most significant of them.

\section{PUBLIC WRONGS AND PUBLIC REALMS}

I begin with Michelle Dempsey's discussion of how we should understand the idea of the (or a) public realm, which is central to my account of crimes as public wrongs (Dempsey 2020). There is much about which Dempsey and I agree: in particular, that criminal law should be understood as a communicative practice in which wrongdoers are held to account, and which serves not merely to sustain, but also partly to constitute the civil order, the character, of the political community (Dempsey 2020: 158-9; Duff 2018: ch. 5.4-6). Our main disagreement is about how to understand the idea of a "public" wrong in this context.

On Dempsey's account, what makes wrongs more, or less, public is the way in which the perpetrator is called to account: a wrong is more "public" to the extent that the wrongdoer is or should be called to account more publicly; and a calling to account is more public insofar as it done, observably, by representatives of a larger group. Thus at one end of the "private"-"public" spectrum we have "comprehensively private" callings to account done by the direct victim on her own behalf, in private; and at the other end we find "comprehensively public" callings to account in public by representatives of "the entire political community" (Dempsey 2020: 165). This is certainly a possible account of the idea of a "public wrong", and Dempsey offers a useful analysis of what it involves; but it is not the (admittedly somewhat stipulative) conception of the "public" with which I work.

For Dempsey publicness is a univocal, scalar matter of how "public" a calling to account is; for me, it is a practice-relative matter that does not permit such a scalar analysis. A wrong, on my account, is a "public" wrong 
if it is one that properly concerns "the public"; and "the public" consists in the participants in the relevant practice or community. Thus in the context of a political community, a wrong counts as "public" if, and only if, it properly concerns the members of that community, in virtue of its bearing on the practice of living together as a political community in which they are engaged; in the context of a golf club, by contrast, a wrong is "public" if and only if it properly concerns the members of the club, in virtue of the practice-playing golf-in which they are engaged together; in the context of an academic institution, a wrong is "public" if and only if it properly concerns the participants in that institution, as bearing on the scholarly, educational practice in which they are engaged. Two implications follow from this; both concern matters on which Dempsey and I disagree.

First, a wrong might be public in the context of one practice, but not in the context of other practices in which the wrongdoer also participates. If I cheat in a golf match, that is a public matter as far as my fellow golfers (fellow members of the club, or golfers anywhere, if we see golf as a practice in which all golfers participate) are concerned. It is their business: they have the standing to call me to account for it; I cannot rebut their challenge by insisting that it is a private matter. However, it is not a public matter in the context of the university philosophy department to which I belong: my academic colleagues, qua colleagues, lack the standing to call me to account for it, since it is no part of, has no bearing on, the practice in which we are mutually engaged; if they challenge me, I can properly tell them that it is none of their business - that I do not answer to them for my conduct on the golf course. ${ }^{7}$ Similarly, my lackadaisical discharge of my academic duties, my failure to mark my students' essays on time, are public matters in the context of my department and my university, but private matters in the context of my golf club: I do not answer for them to my fellow golfers.

Second, to determine whether a wrong should count as a public wrong in the context of a particular practice, we need an idea of what that practice is: what are its distinctive goals and activities; what values structure those activities? Indeed, we can often identify a wrong as a wrong, or as a particular kind of wrong, only by attending to the practice within which it is a wrong: we understand what counts as cheating at golf, and why it matters, by grasping the character of golf as a distinctive kind of practice. That is part of what I meant by arguing that we must start with "the

7 More precisely, I do not answer to them qua colleagues: my cheating is not something that can properly be brought up at a departmental meeting, or made the subject of a disciplinary charge. But if a colleague is also a friend, or a member of the same golf club, she can in that context challenge me about my cheating. 
public" - with an account of the "public realm", the distinctive aims and activities, of the practice within which we are operating: for only then can we identify the wrongs that should count as public within that practice. But "Start with the public" becomes a more important slogan when we imagine ourselves not as agents acting within the framework of an existing, fully formed practice, but as lawmakers-for instance as people charged with the task of formulating the golf club's rules of conduct, or a university's code of ethics. If that is our task, it would be misguided to start with a list of all the wrongs that can be committed, and then ask which of them should figure in the code. We must begin with a conception of the practice's "public realm"- of what kinds of conduct fall within the practice; only then can we identify kinds of misconduct that should concern participants in the practice. Thus the slogan "Start with the public" can also be expressed by saying that wrongdoing, misconduct, presupposes conduct, which presupposes a public realm. A code of ethics, whether for a golf club or a university, or any other social practice, deals with misconduct-not misconduct in general, but misconduct in activities that belong to the practice ("professional misconduct" is misconduct in one's professional activities): to identify the kinds of misconduct with which our code should deal we must therefore first identify the kinds of conduct or activity that belong to that practice. That is why, if we imagine ourselves as tasked not to draw up a code of ethics for an existing practice, but to construct a constitution for a new or newly organized practice, we will not, and cannot, begin with a code of ethics: we must begin by formulating a conception of the practice, of its aims and guiding values, and of the kinds of activity that fall within it; only then can we turn to determining what should count as censurable misconduct in that context. We begin, that is, with a conception of the practice's res publica-its public realm; we are then in a position to identify kinds of wrongdoing that fall within that realm and therefore count as "public" in that context.

As with golf clubs and universities, and other practices and professions, so too (I argue) with political communities and their criminal laws (hence the discussion of codes of ethics in ch. 2). The members of a political community are engaged together in a distinctive practice, of living together as citizens; their criminal law will deal with kinds of wrongdoing that count as "public" in the context of that practice in virtue of their impact on it—on the polity's "civil order"; to identify those kinds of wrong, we must therefore first have some conception of that civil order-of the polity's constitution as a distinctive practice. As analytical theorists or as sociological inquirers, we can understand a polity's criminal law by seeing it in relation to that polity's conception of its civil order, and recognize that different polities are structured by different conceptions of civil order 
(they have different constitutions; hence the discussion of constitutions in ch. 4). As normative theorists, or as active participants in the life of our own polity, we will argue about how this or any polity should conceive its civil order; only on that basis will we be able to argue sensibly about the proper scope of its criminal law-about what it should count as public wrongs, and about how it should respond to them (hence the discussion of liberal republicanism in ch. 5).

We can now see how, although Dempsey and I agree on the importance of "Alternative Sites of Public Accountability (ASPAs)" (Dempsey 2020: 167), we disagree about how they should be understood. On her view, they are different ways of achieving the same end: that wrongdoers are called to account. For any given (kind of) wrong, we can ask which ASPA is most suitable for calling the wrongdoer to account, and we might seek a sensible division of labour between different sites. Thus a golf cheat might be most suitably called to account not by the criminal law, or by his employer, but by fellow members of his golf club (or perhaps by the sport's central governing body): for the club is most likely to be best placed to call him to account; and in doing so it can also help to constitute itself as a valuable institution, which seeks to realise the values of fair play and honesty in its practices. It might be so obvious that given the nature of the wrong and the available ASPAs, the golfer should be called to account by his club, that legislators formulating the polity's criminal law would not even consider cheating at golf (or at games generally) as a candidate for criminalization (unless it involved some financial gain). It remains true, however, on Dempsey's account, that there is reason in principle to criminalize cheating at golf, even though there are obviously better reasons not to do so: for this would help to realise the good of wrongdoers being called to account for their wrongs. This might not be a reason to which legislators should attend in their deliberations: but it figures in "a full philosophical account of the reasons that ... bear on the justifiability" of their decisions about the scope of the criminal law (Dempsey 2020: 171); and it must then surely figure in the thinking of self-reflective legislators who wonder what kinds of reason should figure in their first-order deliberations.

A crucial point, which highlights the difference between Dempsey and me, is that on her account, "in deciding whether any given calling to account is justified" (whether it would, for instance, be right for a legislature to have golf cheats called to account by the criminal law), "we should consider whether and how the wrongdoer will otherwise be called to account"; and one reason in favour of criminalization would be that this "is the only way the wrongdoer will be held to account" (Dempsey 2020: 162). In designing our institutions, we must attend to all those values that might 
be realised through the institution's activities; and one value is that wrongdoers are called to account for their wrongdoing. On Dempsey's view, "if a person can realise a value through her action, then normally she will have a reason to act so as to realise that value": ${ }^{8}$ since criminalizing cheating at games could help realise the value of wrongdoers being held to account, a legislature has reason to do so-although no doubt it has much better reasons not to do so, and not even to think of doing so.

I have two main responses to this line of thought. First, the relevant value here is not that of wrongdoers being held to account, but that of wrongdoers being held to account by those to whom they are answerable; and they are answerable to, and only to, fellow members of the normative practice in which the wrong is done. If a passing stranger seeks to call a golf cheat to account for her cheating, he might succeed in calling her to a kind of account: but he does not achieve the proper end that would be achieved if she was held to account by her fellow members, to whom she is properly answerable for her golfing (mis) conduct ${ }^{9}$ We might miss this point if we think only of more serious kinds of moral wrong, since we might think that those who commit such wrongs are answerable to "the moral community", which includes all moral agents; but we live in other communities than the moral community, with different and more limited scopes.

Second, whether we are acting within some existing practice, or trying to construct one, it is wrong to suggest that we have reason (even in principle) to try so to design our practice as to realise each of all the many possible values-as if those founding a golf club have reason, in principle, to take the promotion of aesthetic appreciation as an aim, and to formulate the club's constitution accordingly (as the normal correspondence thesis implies). It matters that what they are doing has some value, and they might be accused of normative myopia if they attach undue importance to the value of what they are doing: but even if we look for "a full philosophical account of the reasons that actually do bear on the justifiability" of the practice that they construct, that account would not plausibly make reference to all the goods that they could help to realise in constructing the practice.

To which Dempsey might with justice reply that, even if there is some

8 Dempsey 2009: 83 (on "the normal correspondence thesis"); see also Gardner 2007: 62-3, on the "agent-neutralist" view of reasons. This is one part of an ongoing argument about the nature of practical reason between me and theorists such as Dempsey and Gardner: see Dempsey 2011, Gardner 2011, Duff 2013.

9 Analogously, if a vigilante mob lock up an unconvicted offender for the length of time for which he would have been imprisoned if convicted, they might bring about roughly the same material impact that his formal punishment would have brought about; but they do not achieve the end that would justify that punishment- that he be held to punitive account by those to whom he is answerable, his fellow citizens. 
analogy between professions (or golf clubs) and polities, it breaks down just when I need it to do serious work. It might be ridiculous for those creating a golf club, or a profession's constitution, to attend to all the goods that they could in principle realize: but it is surely far from ridiculous, indeed it would surely be entirely proper, for the founders of a polity to think in such terms; and, in particular, if they take seriously the importance of wrongdoers being called to account, they should think about how they can help to realise that good. The first point noted above still remains: that if what matters is that wrongdoers be called to account to and by those to whom they are answerable, it is not clear that a polity could help to realise that end by criminalizing every kind of wrong; for that would presume that wrongdoers of all kinds are answerable, at least in principle, to their fellow citizens-but that is a central point at issue between me and Dempsey. However, why should a polity not take the collective view that, first, every kind of moral wrongdoing in principle falls within its purview, so that those who commit any kind of wrong are in principle answerable to the polity; but, second, that there are many wrongs with which it should not deal directly, since they are better delegated to one of the more specific practices that are found within the polity? Thus, for instance, wrongs committed in the course of medical practice are in principle, like all wrongs, criminalizable as the polity's business; but many of them can be better dealt with through the medical profession's own disciplinary procedures. ${ }^{10}$ Now a polity could coherently take this view of the matter, just as it could take Moore's view of the proper aim of criminal law, as being to inflict retribution on culpable wrongdoers; ${ }^{11}$ and Dempsey is ready to "plead guilty" to offering "a modified version of "Moorean legal moralism" (2020: 172). I think that is indeed what she offers-although the modification is crucial, since it replaces the infliction of retributive suffering by the more plausible goal of calling wrongdoers to account; and I do not offer anything resembling a refutation of either Moorean or Dempseyan legal moralism. But what I do argue against Moore, and would now argue against Dempsey, is that to advocate such legal moralism is to take a particular view of the proper concerns of a polity: that it has an in principle proper interest in every aspect of its citizens' lives, since it has such an in principle interest in all the wrongs that they might commit. Both Moore and Dempsey would then set tight limits on the kinds of wrong in which a liberal polity should actually take an interest; but my claim is that a truly liberal polity would not need to set such limits, because its

10 And I agree that this kind of delegation is sometimes possib profession's own disciplinary procedures le, and desirable: see Duff 2018: 89-91.

11 For Moore's view see e.g. Moore 1997: ch. 1; for detailed critical discussion see Duff 2018: ch. 2. 
initial conception of itself - of the practice of living together as members of the polity, of the aspects of its members' lives and activities that fall within that practice-would not include every kind of wrong. To include every kind of wrong, it would need to include every kind of conduct (for misconduct presupposes conduct): but a central defining feature of liberal as against totalitarian polities is that they precisely reject such a view.

At times I wonder whether the difference between Dempsey and me is substantial: for we agree that a wide range of wrongs (those that a liberal polity would not criminalize) are not in the end the polity's business, and seem to differ only about the stage of deliberation at which "it's not the polity's business" comes into the picture. However, first, that difference matters, if our aim is to understand the proper structure of arguments about criminalization. Second, her account of the idea of the "public" seems to me not to do justice to what we might call the practice-relativity of the public, or to allow a sufficiently basic role to the thought that some wrongs are, from the polity's point of view, categorically "private".

\section{PROFESSIONAL ETHICS AND CRIMINAL LAW}

My account of public wrongs and of the criminal law's role in a political community depends in part on an analogy between criminal law and professional codes of ethics (Duff 2018: ch. 2.7-9). This analogy is the focus of Kimberley Brownlee's paper (2020). Brownlee points out various "problematic features" of existing professional codes-various pathologies to which they are vulnerable. One is that members of a profession are likely to accept without question the moral worth of the practice in which they are engaged, and base their code of ethics on that assumption, whereas a more critical scrutiny might show the practice to be, if not "rotten to the core", morally suspect in some of the aims it pursues or the means by which it pursues them: but if the practice is morally suspect, its code of ethics will fail to identify the kinds of conduct in which its members really ought, or ought not, to engage. ${ }^{12}$ Another problem is that codes of ethics can provide a spurious respectability, an "appearance of ethical credibility" to a profession, so protecting it from critical scrutiny. They can also require members to behave in ways that are, seen from a larger perspective, unethical, and encourage (if not coerce) an uncritical obedience to what

12 Brownlee comments on those who "engage in profit-hungry high finance" (2020: 177): I once heard a talk on professional ethics in the financial sector, during which the lecturer told us that one of the "dilemmas" that people working in the sector faced was "How far should you exploit the customer's ignorance?"; if that figures in your conception of your professional activity as a "dilemma", something is badly wrong. 
the code requires. Brownlee also points out that the distinction (a crucial one on my account) between what falls within the realm of "professional conduct" and thus legitimately concerns other participants in the practice, and what falls outside that realm and thus counts as "private" as far as the profession is concerned, is not a clear-cut or uncontroversial one. Similar problems, she argues, arise if we see criminal law as analogous to a code of professional ethics-indeed, they arise in sharper form. Most obviously, we must ask how members of a polity are to arrive at an acceptable conception of their res publica - of the goals and values that are to structure their collective life; we must recognise the danger that those goals and values will not be ones that are worth pursuing; and we must ask who gets to determine those goals and values, and the laws that are to reflect and protect them. ${ }^{13}$

I agree with almost everything Brownlee says about the kinds of problem that can infect, and undermine the moral authority of, both professional codes of ethics and the criminal law, and I should have made clear that in my discussion of such codes I was not assuming that the kinds of code we actually have are unproblematic: that those whom they claim to bind ought simply to accept them; that the processes by which they are drawn up are unproblematically legitimate; that they reflect conceptions of the worth of the relevant profession that are not to be questioned. I do assume that professions can be of significant value-that such professions as medicine, law, education can (if properly constituted and governed) contribute to human well-being; and that there is good reason for any profession's constitution to include a code of ethics, dealing with the kinds of conduct in which its members should (not) engage in the course of their professional activities, and procedures through which they can be called to account for professional misconduct. I also assume that, however much room there might be for disagreement around the borders, it will be possible, and ethically necessary, to draw a distinction between the "public" and the "private" in the context both of professions and of the criminal law. Now Brownlee seems to accept that codes of ethics, and thus presumably the professions whose codes they are, can be valuable, which is also to accept that they need not "instrumentalize moral reasoning"- that they need not pervert moral thought by making it an instrument of the

13 Brownlee finds my talk of the "Founding Parents" who are, I imagine, to draw up a polity's constitution and its criminal law "jarring", because "it occludes the fact that the people drafting the laws in almost all polities have not been Parents, but Fathers and, indeed, white Fathers" (Brownlee 2020: 188; see Duff 2018: 92-101). My talk of "Parents", rather than of the "Founding Fathers" who loom so large in the rhetoric of the US Constitution, was precisely intended to jar: to remind readers that if we are engaged in normative theory, rather than in positivist description, we must not take for granted the identity of the legislators. 
profession's morally disreputable ends, or serve to protect its members from moral scrutiny (see Brownlee 2020: 182). So is her worry simply that I pay inadequate attention to the ways in which both professions and polities, and their codes, can go wrong: that my discussions display an unwarranted complacency about the kinds of code, and the kinds of criminal law, that we actually have? I think there is more to it than thatand that "more" highlights an important aspect of my account.

One problem, in Brownlee's eyes, seems to be that my account, both of professional codes and of criminal law (or of a polity's civil order, from which its criminal law will flow), is set in overly "formal" terms that do not allow us to distinguish the substantively acceptable from the unacceptablethose that are created, by suitable procedures, to serve worthwhile ends by morally appropriate means, from those that are not: I must recognize (as an "extreme example") that the SS had a code of ethics (Brownlee 2020: 177); and the "formal" character of professional codes too often serves to conceal, rather than to illuminate, the substantive moral values by which the profession's members ought to guide their conduct (2020: 179-80). There are two distinct worries about formalism here.

The first concerns the character of the codes and the role they play in professionals' lives: if they are expressed as sets of formal rules, which the members are simply to obey without further (self-)critical thought, they can indeed have the kind of morally blinkering effects that Brownlee highlights; similarly, if citizens see their criminal law simply as a set of rules that they are to obey, this is likely to blind them (or to help them blind themselves) to the more nuanced moral considerations that should guide their actions. However, that is an objection not to professional codes of ethics as such, but to some of the ways in which they can be formulated and treated; and, in the case of criminal law, I argued that the criminal law of a decent polity will not be a set of prohibitions or rules that citizens are simply to obey. The citizens will maintain a critical attitude towards their criminal law, as a fallible attempt to express the polity's shared values; they will be ready, as good citizens, to act if necessary in ways that it defines as criminal; and even when it can claim their allegiance rather than their critical opposition, they will apply it with a critically discretionary understanding - they will not simply follow it blindly. There are questions, in particular in the context of the kinds of regulation whose breach constitutes a malum prohibitum, about when we should subject our conduct to relatively strict, formal rules-for instance to regulations specifying the maximum speed at which we may drive, rather than to the injunction not to drive dangerously (see at nn 30-32 below): but neither codes nor criminal laws need be "formal" in ways that distort our practical reasoning. 
The second worry concerns the "formal" character of my account of both professional codes and the criminal law: that it makes room for, or allows in, codes that serve the ends of morally repugnant "professions" (like the SS), or that fail to capture the moral considerations that should guide the profession's members; that it makes room for profoundly undemocratic systems of criminal law that function to protect the interests of the powerful rather than to serve the common good. This is certainly true-up to a point. My initial aim was to give a rather formal account of criminal law (as involving the definition of a set of public wrongs and the provision of a process through which those accused of such wrongs would be called to public account), and of the idea of civil order (and of a polity's constitution) in which the criminal law is to be grounded; analogously, my aim was to provide a rather formal account of professional codes of ethics, which did not try to say anything substantive about the aims a profession should pursue, about which professions are worthwhile, or about the appropriate content of their codes of ethics. The account is not purely formal: not anything could count as a profession or professional code, or as a conception of civil order, or as a system of criminal law. But it counts as professions both the good and the bad, so long as they can be seen to be oriented towards some intelligible conception of a good that is worth pursuing; it counts as codes of ethics codes that can be seen to govern members' conduct in the light of that good $;{ }^{14}$ it counts as polities with conceptions of their civil order utterly undemocratic societies that are oriented towards substantively unacceptable goals, or that take substantively unacceptable views of what counts as "public" or as "private", and the content of whose criminal codes is therefore substantively unacceptable. ${ }^{15}$ For a current example, if the Indonesian parliament enacts its proposed new criminal code, which criminalizes "living together outside marriage" and "extramarital sex", ${ }^{16}$ that will be a genuine criminal law, which reflects a conception of Indonesia's civil order as including matters concerning marriage and sexual relationships that, in western liberal societies, count as "private"; that code, and that conception of civil order, might not have been arrived at through a process of democratic deliberation, but that cannot disqualify them from counting as a conception of civil order and as a code that gives expression to it. Am I therefore committed to approving that criminal code, that conception of civil order, as acceptable-if not

14 And even codes that are purported thus to govern members' conduct, but are better understood as covers for the profession's unethical aims; to count these as codes of ethics is also to make clear that they are to be assessed in the light of their purported aims.

15 "Substantively unacceptable" to whom, or by what criteria? See s. 5 below.

16 See https://www.theguardian.com/world/2019/sep/20indonesia-hundreds-ofthousands-oppose-plan-that-would-outlaw-extramarital-sex. 
universally or for "us", at least for Indonesia? Of course not-just as in recognizing that someone who believes that homosexual conduct is morally wrong, or that it is morally permissible to factory farm animals, holds a genuine moral view I am not thereby committed to endorsing that view as acceptable.

In theorizing about criminal law (as about morality), even if our aims are normative, we should distinguish different stages or elements, only some of which are (directly) normative. We may begin with a (relatively) formal account of criminal law, as I do in ch. 1; we might add, as I do, a relatively formal account of the role of criminal law, as thus understood, in the structure of a political community (this will include a formal account of the idea of a political community). This might lead us to the formal principle of criminalization that I advocate: one that is formal in that it leaves open the question of what substantive content is to be given to the concepts of "civil order" and "public wrong". The point of beginning with such a formal account is partly to clarify the nature of the practice we are theorizing; but also to bring into view the kinds of argument that are relevant to assessing, justifying or criticizing systems of criminal law. One who wants to justify a criminal code must, if my formal account is right, be able to argue that the conduct it defines as criminal is a public matter, and is wrongful, and must therefore also be able to articulate a conception of the polity's civil order in which such conduct will count as public and wrongful: but there are limits of intelligibility on what can even count as a conception of civil order or of public wrongs; and in offering such arguments the advocate will bring her claims within the reach of normative political, legal and moral appraisal—she will have to subject those claims to those kinds of appraisal.

A second stage or element is roughly procedural: we discuss the kind of process through which a polity's (self-)constitution, its conception of its civil order, and its criminal law are to be constructed. We cannot say, a priori, that those processes must be in any way democratic: monarchies and oligarchies are political communities, structured by some (nondemocratic) conception of civil order, and maintaining systems of criminal law. But, changing gear from the analytical to the normative, we can argue that a decent polity, one we could recognise or accept as a respect-worthy political community, must be democratic in its self-constituting procedures (we will then need to go on to discuss which kinds of procedure should count as "democratic"). Familiar questions now arise about who "we" are to make such arguments, and what purchase they should rationally have on non-democratic rulers: about, for instance, whether we can rationally demonstrate that a polity must be democratic if it is to have any justified 
claim to legitimacy or authority —and about what follows, in terms of the claims or judgments that we can properly make, if we must accept that no such rational demonstration is available (questions, that is, about "relativism"). We need not pursue such questions here: we need only note the familiar point that impeccably democratic procedures can produce conceptions of civil order, and of what counts as a "public wrong", that "we" (postponing again the question of who "we" are) find unacceptable.

If we take a positivist, detached stance, we can describe the conception of civil order that a polity espouses, and the conceptions of public wrongs and the proper scope of its criminal law that flow from that conception: in $P$, we might say, the civil order encompasses sexual relationships, and a heterosexual view of the kinds of sexual relationship that are legitimate; in $P$, accordingly, and consistently with that conception, other kinds of sexual relationship are criminalized as public wrongs. This does not commit us to endorsing P's criminal law: once we replace our positivist hats by more committedly normative hats, and engage (as citizens, as external critics or as normative theorists) in substantive argument about how we, or they, should conceive their civil order and their criminal law, we can argue that consensual sexual relationships should be seen as falling, as far as the polity is concerned, within the "private" rather than within the "public" realm, and/or that non-heterosexual relationships should be accepted and recognized as valuable; and so on. Once we make this move to substantive normative arguments about the content of civil order or of the criminal law, we are at the third stage or element of our theorizing - a stage in which I did not seriously engage in this book (although in ch. 5 I sketched, as an illustration, what I take to be a plausible substantive conception of a republican polity). This was not because I think this stage unimportant; it was because I wanted to make clear the crucial initial stages of a theory of criminal law.

In brief, then, Brownlee is right to highlight the kinds of deficiency or pathology that can affect (infect) professional codes of ethics, and the criminal law; she is right to point out the ways in which such codes can distort or subvert the kind of ethical thinking that should guide the conduct of members of professions (and of citizens): that is why members of professions need to take a suitably (self-)critical stance towards their professions' self-justifications and their codes; that is why citizens need to maintain a (self-)critical stance towards their polities' conceptions of their civil order and towards the criminal laws that help to sustain that order. But none of this is a threat to the (quite limited) analogy that I drew between the criminal law and professional codes of ethics; nor does it undermine the claim that criminal law can serve an important and 
valuable role in the life of a political community, just as a code of ethics can play an important, valuable role in the life of a profession.

\section{MULTICULTURALISM AND DEMOCRATIC DIALOGUE}

I have talked about a political community and its members; about how they can develop and articulate a conception of their civil order, and an account of the shared values that structure their civic enterprise of living together as fellow citizens. Such talk makes sense, it might be said, in societies with culturally homogenous populations: societies whose members can be said to share a form of life, and who can be expected to agree on the key values that inform that way of life. This is, however, not our present condition, as Roberto Gargarella forcefully reminds us: the societies about whose criminal laws contemporary criminal law theorists seek to theorize are characterized not by cultural homogeneity or agreement, but by deep diversity and difference. The pressing question then is whether and how we can normatively theorize criminal law in ways that do justice to the facts of "multiculturalism": Gargarella argues that my account fails to do adequately democratic justice to multiculturalism (Gargarella 2020). Indeed, his critique is broader than that: although, on my account, the voice of the criminal law should be the voice of the political community, my account does not make that possible, whether or not the community is a multicultural one.

I do not think that Gargarella and I disagree, or need disagree, as much as he supposes we do. To show why that is so, I begin with four preliminary points, to clear up what might have been some misunderstandings.

First, Gargarella takes me to define "public wrongs as faults that 'are clearly inconsistent with, manifest violations of, any remotely plausible conception of civil order", or "conducts that are 'intrinsically ... inconsistent with civil order"' (Gargarella 2020: 195-6, quoting Duff 2018: 300 ). But I am not there discussing public wrongs in general: I am talking only about murder and rape as, I supposed, obvious examples of kinds of wrong that any polity ought to criminalize; I accept, as an implication of my account of the relationship of criminal law to civil order, that we will find differences both within and between polities about many public wrongs-about which kinds of conduct should be seen as public matters, or as wrongful. All I meant to claim was that it is hard, perhaps impossible, to imagine a polity whose members share a conception of their civil order according to which it is not a public wrong to kill any other person at will, or to force sexual penetration on others regardless of their will. That is not 
to say that we cannot all too easily imagine a society in which members of some groups are treated as "fair game" for members of the dominant group: it is only to say that we cannot imagine a community (as distinct from a mere aggregate of individuals living within the same geographical territory) in which everyone is fair game for everyone else; and that a society in which members of one group were in that way fair game for members of another, dominant group would not be normatively plausible, or a society of citizens living together. Indeed, that claim is even stronger if we accept Gargarella's account of how a society ought to go about determining its voice and its laws - through a

"public, collective conversation, where each person participates as an equal together with all the others. Every voice has then to be listened, every viewpoint has to be considered, every interest has to be taken into account" (2020: 205).

Such a conversation would predictably lead to different substantive conclusions in different groups or communities, but there are constraints on those conclusions. For if the participants are to view and treat each other as equals, that requires a mutual respect between them, which is inconsistent with seeing some other participants as fair game who can be killed or sexually coerced at will.

Second, even in cases in which I take it to be uncontroversial that any polity must count some wrongs, such as murder and rape, as public, criminalizable wrongs, I do not suppose that their precise definitions as public wrongs will be unproblematic. Any non-pacifist polity will allow, for instance, that killing another is sometimes permissible: so a polity will need to decide just how to define murder as a public wrong; and here there will be ample scope for disagreement. So too with rape: apart from the question of whether there should be a distinct crime of "rape", as opposed to various crimes of (sexual) assault, ${ }^{17}$ there is a familiar range of difficult questions about the precise scope and definition of the crime. That is why I note that the process of defining even obvious mala in se as crimes is a process of construction (Duff 2018: ch. 7.4): we cannot simply reproduce in our criminal law some already available pre-legal understanding of just what the wrong consists in.

Third, one of my claims is that the criminal law's offence definitions must purport to be, or be justified as, definitions of kinds of conduct that are already wrongful independently of the criminal law. Some are (allegedly) pre-legal wrongs, wrongful independently of and prior to the 
law: these are "mala in se". Others are wrongful only in virtue of the law, for instance in virtue of a legal regulation that prohibits them, and are thus not pre-legally wrongful: but they must still be wrongful independently of the criminal law that criminalizes them; these are "mala prohibita", which are pre-criminally, but not pre-legally, wrongful. ${ }^{18}$ So when I say that the criminal law does not create the wrongfulness of the mala in se that it criminalizes, but rather "declares that these pre-existing, pre-legal wrongs" are public wrongs (Duff 2018: 123; see Gargarella 2020: 200), all that I mean by "pre-existing" is "pre-legal"-existing prior to the law. If we then ask whether such wrongs can be said to "pre-exist" not just the law, but the (or any) political community, we enmesh ourselves in questions about the metaphysics of value that neither Gargarella nor I need to tackle for our present purposes. We are neither of us relativists (Gargarella 2020: 195): thus while we can agree that in some sense communities "construct" the values by which they live, their constructions are not immune to criticism; dissident participants or interested observers can argue that they are wrong. We need not here tackle the further question of what kind of metaphysical foundation such criticism requires.

Fourth, my "oscillations between liberal and communitarian positions" are said to create "confusions" (Gargarella 2020: 192) —as if one cannot consistently be both a "communitarian" and a "liberal", which is what I claim to be. Now on Gargarella's understanding of liberalism, that is a fair point: for he takes the distinction between liberalism and communitarianism to be one "between the universal and the communal; the general and the particular; the critical view about the structures in which we live, and the attachment to the communities where we live"; between "shared, localized, communal values" and "more universal values" (2020: 198). Thus whilst "liberals" will insist on assessing the values espoused by particular communities in the light of (supposedly) universal values, "communitarians" cannot, it seems, take such a critical stance towards local values. But that is not the sense of "liberal" in which I claim to be a liberal, nor indeed the sense of "communitarian" in which I claim to be a communitarian - although given the variety of possible meanings for each of those terms, I should have made my usage clearer, which is what I

18 I thus defend (Duff 2018: ch. 2.3-4) a "Strong Wrongness Constraint". I should comment briefly here on the cautionary "(allegedly)" in "Some are (allegedly) pre-legal wrongs". Gargarella picks up on a cognate remark that the criminal law "must speak, or claim to speak, in the voice of" a political community (2020: 203; see Duff 2018: 110), and rightly notes that speaking and claiming to speak are very different things. All I meant was that if the law is to make a claim on our allegiance it must claim to speak in our voice, and we can then discuss whether that claim is justified; only if that claim is justified does the law have a justified claim on our allegiance. 
will now try to do (see further Duff 2001: ch. 2).

Communitarianism is opposed not to liberalism (in all its forms), but to a particular type of "individualism", according to which political deliberations must always begin (and end) in the first person singular: each person must ask: "How am $I$ to live?". For communitarians, the question must of course be answered, in the end, by each person: but the question to be asked is "How are we to live?"; and the "we" are the members of a particular, and inevitably local, community in which the asker finds herself or himself. ${ }^{19}$ Thus the values by which a political community is to live are necessarily local: they cannot but be the values that the members of that community understand as theirs. (Democratic communitarians will go further than this, to argue that the values by which a political community is to live ought to be determined by its members by a process of democratic deliberation.) There is thus no "view from nowhere" (Nagel 1986), from which we can determine the values that should guide a polity; political deliberation must begin from, be grounded in, somewhere-some particular local community of thought. But two things, which worry Gargarella about my view, do not follow from this.

First, it does not follow that a community's values cannot be criticized either by its members or by outsiders. Even if we can imagine a community whose modes of thought, whose normative and conceptual structures, are so monolithic, and so insulated from others, as to leave no room for internal dissent to even make sense, and no scope for external critique via shared concepts or values, ${ }^{20}$ the political communities that actually exist are not like that: there is conceptual room, even if in more totalitarian polities there is no normative welcome, for internal critiques; and there is room for critiques from outside appealing to values that are, if not currently espoused by the polity, at least accessible to it.

Second, it does not follow that a political community cannot espouse liberal values-or that critics cannot argue that it should do so: values such as individual autonomy or freedom, privacy, equality, "equal concern and respect" (Dworkin 1986: 190)—although those values would, on a communitarian account, be given a communitarian interpretation as values that structure our lives together. That is how I can be a liberal

19 I say "inevitably local" for two reasons. First, the scope of any community is contingent, however large it might in fact be, whereas the "universalism" with which Gargarella is concerned is a priori, concerning all rational beings. Second, as a matter of fact, the political communities in which humans live are relatively local rather than global: whatever power there is to the idea of a cosmopolitan community of "humanity", political communities as we have them are much more local.

20 Though even Oceania, in Orwell's 1984, did not manage to achieve this. 
communitarian: I can hope to live in a polity structured by liberal values; as a member of this polity, I can argue that we ought to espouse liberal values; I can argue with members of other political communities, which do not espouse liberal values, that they ought to do so-not by appealing to some supposedly a priori universal values binding on all rational beings, but by appealing to the conceptual links that exist between their existing values and liberal values. Thus, to take one of Gargarella's examples (2020: 197-8), someone who mocks the traditions and way of life that Catalans regard as important to their identity as a political community, might be seen by Catalans as attacking their res publica. But, first, this is not necessary, since their conception of their res publica might include a commitment to robust political debate of which this kind of critique is a part. Second, even if it is an attack, they can be committed to a liberal value of freedom of speech, given which such attacks must be tolerated, if not welcomed-and we could argue, either as Catalans or as outsiders, that they ought to be thus committed.

With these preliminaries out of the way, we can turn to Gargarella's central concern: that my account cannot do suitably democratic justice to multiculturalism, or to the manifest fact that we do not live in normatively homogenous communities. The problem here might take two forms. First, we can imagine that several culturally and normatively distinct groups, or a large number of individuals with very different values, share a territory and have to work out how they can live together, given that they are roughly equal in power: the question then will be whether they can come to agree on enough in the way of values and procedures to make it possible to live together as a political community-as distinct from living beside each other in a state of uneasy co-existence. That is not, I think, the version that worries Gargarella-or the version that we typically find in our contemporary world. The more usual version is that an existing polity contains a dominant cultural group (dominant perhaps in numbers, certainly in power), and one or more weaker groups; or a dominant majority and a dissenting minority who do not share the majority's core values. What is to be done in such situations?

A tempting way to approach this question is to ask what "we" should do about such non-powerful minority cultures, or such dissidents: what can "we" say to "them"; how far should "we" tolerate "their" different values and customs, or allow "them" to live by their distinctive values? But, as I think Gargarella and I agree, that is a dangerously misleading way to put the question: for it implies that those who must answer the question, the 
"we", are the members of the dominant majority; and that they, and only they, must decide what to do about or to or with these others. That is what all too often in fact happens: but if the question is what should happen in a polity that aspires to democracy, the "we" who decide what to do must include all those in the polity, in a democratic deliberation in which every voice can be heard, and is heard with attention and respect-in, as Gargarella puts it, "a public, collective conversation" (2020: 205). What form that conversation should take, how it should be institutionalized (since any large polity needs institutions to actualize its democratic aspirations), who is in the end to speak for "the polity" - these are familiar issues for democratic theory, on which I won't take a view here. But whatever form that conversation is to take, it must end with a decision (or, if no decision can be reached, with the collapse of the polity): one that we cannot realistically expect to be unanimous, even if we can hope for something close to unanimous agreement on the kind of procedure by which it is to be reached. We (the "we" who constitute the polity) must address and listen to each other respectfully: we must try to understand the values by which others want to live, which might require us to try to understand the distinctive way of life in which those values are embedded; we must see whether disagreements can be resolved through discussion, so that those who initially disagreed about how to live can come to agree; if we cannot agree on those substantive questions, we must try to agree on where differences should be accepted-you live your lives, we live ours (bearing in mind that the "you" and the "we" are still fellow members of a larger "we"). I think that Gargarella and I also agree on two further points.

First, we are not relativists who would say that each culture must be left free to determine its own way of life (see Gargarella 2020: 195): ${ }^{21}$ it must be open to "us" to come in the end to the view that a particular culture should not be allowed to continue with this or that culturally embedded practice (with a practice of "female genital mutilation", for instance, or of "honour killings" of disobedient daughters), ${ }^{22}$ even if that is not a view that members of the particular culture can be persuaded to accept. Second, as should already be clear, we do not believe that the dominant group should claim the right simply to enact (to "impose") its own values: even if they have the

21 I am talking here of how "we" are to deal with multiculturalism: the issues raised by individual dissenters or rebels have the same form, and can be addressed in the same way (see further Duff 2018: chs 3.4, 5.7).

22 It is worth noting how disagreement about the permissibility of certain practices is also disagreement about how they should be described-hence the scare quotes in this bracket. 
effective power to do so, they must engage as citizens with all their fellows, seeking to build a "we" that includes everyone in the "public, collective conversation". ${ }^{23}$

In the end, however, and assuming that quite often we will be unable to agree either on the substantive issue or on whether we should simply accept difference, there will need to be a decision procedure, from which will emerge (if the polity can survive at all) something that can count as the polity's view, and therefore as "our" collective view; and there will then be people (officials of some kind) who are entitled to speak and act in the community's name. If there is to be a criminal law (something that requires argument, but that Gargarella does not seem to deny), it will then define as public wrongs some kinds of conduct that some members of the polity will not see as wrongs. I offer no view here on what those should be, but again emphasize the importance of distinguishing the procedural from the substantive stages of the argument. We can argue first about the procedures through which a democratic polity should determine its laws; and we can argue secondly about what the substantive outcome of those procedures should be-for instance when we engage, as citizens, in the public conversation that will determine our laws: but we must recognize that the outcome of a democratically impeccable procedure might be one with which we substantively disagree-that is a familiar truth about democracy. All of which is to say that both Gargarella and I recognize the serious problems raised for would-be democrats by the facts of deep cultural differences and deep normative disagreements within contemporary polities; we agree that such problems must be addressed within the polities themselves, through a democratic deliberation in which every citizen has an equal voice; we recognize that such deliberations may result, not in unanimous agreement, but in a decision with which some will be unhappy; and we therefore realize that there can be no clean and simple route to a resolution of such disagreements-only the messy processes of democratic deliberation.

23 There are then further familiar problems about the possibility of such conversation: suppose that one group refuses even to listen to the kinds of argument that another group offers (one aspect of the problem of "public reason"), or denies that certain kinds of people (identified by gender, or race, for instance) should have an equal voice, or any voice, in the conversation. Although the appeal to democratic conversation generates a largely procedural account, the procedure itself involves certain substantive pre-commitments about the standing of those who are to engage in it. 


\section{PRINCIPLES OF CRIMINALIZATION}

I must turn now to issues more directly concerned with criminalization. Tatjana Hörnle and I agree that we cannot expect to articulate a single thick master principle of criminalization-a principle providing determinate substantive criteria by which to decide what kinds of conduct we have good reason to criminalize: any such principle will either be too narrow, as failing to capture kinds of wrongful conduct that we clearly have reason to criminalize; or become so diluted, as it is revised or extended so as to capture every kind of criminalizable conduct, that it can no longer offer substantive guidance (Hörnle 2020; see Duff 2018: ch. 6). My response to this critique of "single principle" theories of criminalization is still to offer a single master principle, but one that is avowedly very thin: the "public wrongs" principle explained in s. 2 above. Hörnle's response is different: she argues that we can still identify determinate, thick principles of criminalization; but that we need two (or even three) such principles, rather than just one, if we are to capture all the kinds of conduct that there is good reason to criminalize.

I discuss Hörnle's proposed principles below, but should first make two brief comments on the relationship between her account and mine. First, her substantive principles could be seen as complementary to, rather than as competing with, the thin principle that I offer-as spelling out in more substantive terms the criteria by which we are to identify relevant public wrongs: a type of conduct constitutes a public wrong if it is incompatible with an important collective interest, or violates another's right to nonintervention. Second, a merit of the kind of thin principle that I offer is that, whilst it does not provide substantive guidance about what kinds of conduct we have reason to criminalize, it shows what kinds of argument are relevant for, or against, criminalization: thus whilst it might not directly address the "genuine puzzlement" of legislators or civil servants deliberating about criminalization (Hörnle 2020: 212), by offering them direct guidance on what they should or should not criminalize, it can help them to see what kinds of reason they need to consider, what kinds of argument they need to offer.

Now for Hörnle's proposed principles. Two are responsive principles concerning conduct that violates others' rights "to non-intervention": we categorically must criminalize all violent attacks that violate "important rights of others"; and we have good reason to criminalize other kinds of 
violations of the right to non-intervention. ${ }^{24}$ How thick are these principles; and how complete, as regards kinds of criminalizable conduct that do not violate collective interests? As Hörnle points out, if our topic is criminal law, we must be concerned with rights as they figure in our relations to each other not simply as moral agents, but as citizens: with, I would say, rights as they figure within, or bear on, the civil order in which we live as citizens. ${ }^{25}$ As she also points out, there is no serious dispute about the criminalizability of the most obvious kinds of right-violation in this context, such as murder, rape, and other kinds of violent attack on the person (although there is room for argument about just how we should define these as crimes). She also argues that we can distinguish a "core" set of rights-violations that we must criminalize from other kinds of violation that we have only pro tanto reason to criminalize, and that I do not do justice to that core set, since I say only that we must criminalize them if we have a system of criminal law-whereas she argues that we have "a categorical duty to create criminal law in the core area" (2020: 216; see Duff 2018: 277). This is not a significant disagreement, since I explain later (2018: 299-301) why such wrongs must count as serious public wrongs, which we have very good reason to criminalize. I do not, it is true, insist with Hörnle that we must create criminal law in order to criminalize them: for I would not rule out $a$ priori the possibility that a polity could find suitable ways to mark and respond to such wrongs that might not count as "criminal law"; but I agree that they violate values that must be central to any plausible polity's conception of its civil order, and are inconsistent with the most basic requirements of civil order. However, first, to see why these are such obviously, indisputably, central kinds of public wrong, we need to appeal to a conception of a polity—of, as I would put it, civil order; or, as Hörnle puts it, of what it is to be a citizen living with other citizens. Second, how are we to distinguish "core" rights-violations, which must be

24 Hörnle seems to think (2020: 216) that I would deny such essentially responsive principles, since I think that the criminal law is "essentially preventive", but my view is the reverse of this. In the passage from which she quotes (Duff 2018: 261), I begin by noting that on my account criminal law is "essentially responsive", but then add that it is "also essentially preventive, or perhaps ... persuasive". Thus I agree that in the case of violent rights-violations the primary reason to criminalize is responsive; I differ from her, as we will see, in that I would say the same about our reasons to criminalize conduct that violates important collective interests.

25 Another point of clarification. Hörnle argues, criticising my account, that “[c] rimes against persons are not foremost conduct that violates the civil order. They are this, too, but this is not the most salient description. The main feature is interpersonal" (2020: 214). I agree: the wrong that we have reason to criminalize, what I call the object of criminalization, consists precisely in the violation of another's rights; that it violates the civil order is relevant purely as a condition of criminalization, as making that wrong the collective business of the polity and its citizens (see Duff 2018: 216-7). 
criminalized, from other kinds of violation of the right to non-intervention? Hörnle specifies “individuals' most important rights (rights to life, bodily integrity, sexual autonomy, freedom of movement, freedom from coercion)", violent attacks on which will then form the core of criminal law (2020: 215): ${ }^{26}$ but it is not clear, at least to me, why only violent attacks should count; or whether every kind of violent attack (including for instance minor physical assaults) must count; or why only these rights, and the interests that they protect, should be included. More significantly, it is not clear why we should try to draw a sharp distinction between the core and the non-core-rather than saying, more plausibly, that we can distinguish along a spectrum (or two spectra) more from less important rights, and more from less significant kinds of violation of them; and that the more important the right, and the more significant the violation, the stronger our reason to criminalize it.

If we abandon, as I suggest we should, Hörnle's sharp distinction between core and non-core, we are left with just one principle in place of her latter two: that the "state has reason to criminalize conduct if it violates another person's right to non-intervention". ${ }^{27}$ But how thick or substantive is this principle? We need, of course, an account of what kinds of conduct are to count as "intervention", and of what kinds of intervention violate rights. I cannot pursue this in detail here, but would suggest, first, that any account of "wrongful intervention" must appeal to a conception of civil order, since only on that basis can we give an account either of what counts as intervention (since intervention must be into a sphere one can count as one's own), or of which kinds of intervention are wrongful: but in that case, in giving an account of rights to non-intervention we are already giving an account of public wrongs, and the notion of "rights to non-intervention" proves to be hardly thicker than that of "public wrongs", save that it focuses our attention on wrongs with individual victims. For we are giving an account of the kinds of conduct that we are entitled to expect or demand of each other, as citizens-or of the kinds of conduct about which we are entitled, as citizens, to complain: whether we call such complaintgrounding conduct victimizing public wrongs, or rights-violations, we are in effect saying the same thing. Thus to ask whether, for instance, we have reason to criminalize conduct that violates dignity would be, on Hörnle's account, to ask whether citizens have a right not to be treated with indignity-whether this constitutes a wrongful intervention. On my

26 Though she should presumably, given what she and I agree on (see above), talk of the most important rights of individuals as citizens.

27 2020: 220. She adds "(however, there might be countervailing reasons)", but that seems unnecessary: if a principle says only that we have reason to criminalize, that leaves open the possibility that there might be other, countervailing reasons in. 
account, it is to ask whether our civil order should be defined, in part, in terms of respect for dignity: these seem to me to be in effect the same question, in which case Hörnle's rights-violation principle is hardly thicker than my "public wrong" principle.

Second, we must also ask whether all victimizing crimes could be portrayed as violating a right to non-intervention-without depriving that right of any substantive content. Familiar examples will surface here: crimes of omission - of failing to help someone in desperate need (can such failures be portrayed as wrongful interventions?); or crimes committed against the dead such as corpse desecration (see Jones 2017); or crimes against non-human animals. ${ }^{28}$ The key question is again whether these are wrongs that should concern us as citizens, in virtue of their incompatibility with some value internal to our civil order; I do not see that it helps much to translate that question into one about rights.

I turn now to Hörnle's other principle, concerning the protection of collective interests, and begin with a clarification. Hörnle insists that this principle, unlike those which deal with rights-violations, is "straightforwardly preventive" (2020:213), but she conflates two different types of (apparently) preventive principle. One is indeed "straightforwardly preventive": "We have reason to prohibit X if this will prevent harm" ${ }^{29}$ The other, by contrast, looks initially responsive: "The state has reason to criminalize conduct if it is incompatible with important collective interests" - though it adds "that cannot be adequately protected by other means" (2020:219-20). The former principle is purely preventive and forward-looking: we are to ask simply whether prohibiting this type of conduct will prevent harm to collective interests; and although the obvious way to prevent such harm is to prohibit conduct that is likely to cause such harm, we might sometimes secure preventive benefits by introducing regulations that also prohibit conduct that is neither harmful nor dangerous. The latter principle, by contrast, is responsive, since it requires criminal sanctions to be a response to conduct that itself violates or threatens a collective interest, even if the purpose of that response is (in part) to prevent future harms. The difference between these two types of principle can be illustrated by driving offences. If we criminalize dangerous driving or driving when rendered unfit through drink or drugs, ${ }^{30}$ we criminalize conduct that is itself incompatible with important collective interests-and is for that reason wrongful. If instead

28 See e.g. (Animal Welfare Act 2006). Hörnle notes the possibility of appeals to animal rights (2020: 213, n. 5); but it seems to me unnecessary to go down that road.

29 Hörnle 2020: 213. She cites Duff 2018: 238, where I talk of having reason to criminalize a type of conduct if by doing so we will prevent harm; as we will see, the replacement of "criminalize" by "prohibit" matters.

30 See e.g. Road Traffic Act 1988, ss 2, 4. 
we prohibit driving at more than a specified speed, or with more than a specific proportion of alcohol in one's blood, ${ }^{31}$ we are likely to prevent harm more efficiently, but we do this by including within the prohibition conduct that is not itself harmful or dangerous, since not all of those who break the speed limit, or drive with a higher than permitted level of alcohol, will be driving dangerously or be impaired. Such prohibitions are not yet criminal laws, since they do not mark the prohibited conduct as being wrongful (as criminal laws mark the conduct they define as criminal); the criminal law comes into the picture only when we criminalize, as wrongful, breaches of these kinds of regulation. ${ }^{32}$

Of these principles ("We have reason to prohibit $\mathrm{X}$ if this will prevent harm", "The state has reason to criminalize conduct if it is incompatible with important collective interests"), the latter is indeed a principle of criminalization, so long as we can say that conduct that is incompatible with important collective interests is for that reason wrongful: for if it is thus wrongful, it constitutes a public wrong in a very straightforward way, as impinging directly on a public interest. But our reason to criminalize is then, as in the case of rights-violations, as much responsive as preventive, since in both cases the publicly wrongful character of the conduct gives us reason (makes it appropriate) to respond to it by calling the wrongdoer to formal public account through a criminal process. In both cases, we also have a preventive interest; but what is intrinsic to criminalization is the responsive dimension. What is true is, admittedly, that when it comes to the question of whether we should criminalize all things considered (as distinct from the initial question of whether we have reason to criminalize at all), the balance between responsive and preventive considerations might differ as between different kinds of wrong. Perhaps responsive considerations will weigh more heavily in the case of serious wrongs, whilst preventive considerations will be more prominent with less serious wrongs: we might see strong or even compelling reasons to criminalize very serious wrongs, even if by doing so we do not expect to achieve much in the way of prevention; ${ }^{33}$ whereas with (relatively) minor wrongs we might think that we should criminalize (rather than responding in some other way) only if this would be preventively efficient. Even so, this does

31 See Road Traffic Regulation Act 1984, ss 81-9; Road Traffic Act 1988, s. 5.

32 On these two kinds of principle, and the distinction (important to understanding the character of so-called "mala prohibita") between criminalization and regulation, see Duff 2018: 21, 65-8, 237-48. Another issue (Duff 2018: 16-19, 284-6) is whether we should maintain a (formally) non-criminal system of regulations whose violations do not (formally) count as criminal, like the German system of Ordnungswidrigkeiten.

33 Even if we expect no preventive effect? As Hörnle notes (2020: 216) it is hard to imagine such a case; and if criminal law as a whole has some preventive efficacy (and this is necessary to its justification), consistency requires us to criminalize serious public wrongs even if in particular cases this is not preventively effective. 
not support Hörnle's claim that the principle concerning conduct that violates collective interests is a preventive principle, whereas that concerning conduct that violates others' rights is responsive (Hörnle 2020: 213-216). It would support her claim if violations of individual rights were always more serious than violations of collective interests, but that is surely not true: compare treason, or large scale tax evasion or fraud against the public purse, with damaging another's property or a minor physical assault.

We must also ask of Hörnle's "collective interests" principle, as of her "rights-violations" principle, how thick it is; and the answer is again that it is almost as thin as my public wrongs principle. For we must first identify the collective interests of the members of the polity (and assess how important each is): which we can do only by getting clear about the character of the polity, and the interests that its members share in virtue of their membership—about, that is, the polity's civil order. Hörnle is scathing about the German Rechtsgutslehre, according to which we have good reason to criminalize conduct that violates or threatens a "Rechtsgut", a legally protected good: the concept of a Rechtsgut is, she says, "not only a thin concept, but so thin as to be an empty concept" (2020: 212). Now I would not myself call it "empty", since there will be constraints at least of intelligibility on what one could count as a good worthy of recognition or protection by the law; but if it is empty, so too is that of a collective interest, since to work out the interests of either an individual or a group, we must first have some idea of the good of that individual or group. We can try to distinguish criminal laws that protect, or respond to violations of, individual interests or rights from those that protect, or respond to violations of, collective interests, ${ }^{34}$ and in both contexts there will be plenty of obvious cases of conduct that we of course have reason to criminalize (because, I would say, in such cases it is obvious that any plausible polity must count them as public wrongs): but when the cases become controversial or unclear rather than easy, I do not think that Hörnle offers a principle that is both thick and plausible in either the individual or the collective context can.

\section{A RIGHT TO BE PROSECUTED-AND A DUTY TO FACE TRIAL?}

Finally, I turn to Gustavo Beade's interesting discussion of "the right to be prosecuted" (Beade 2020). Beade's leading example is Mr Lamb, who makes some (to put it mildly) intemperate remarks at a promotional event,

34 Though this will sometimes involve controversy, for instance about the normative grounding of property crimes (on which see Simester and Sullivan 2005). 
about the legal age of sexual consent, about rape, and generally about law. Given their context and their topic, his remarks are clearly a public matter: they are, it seems, intended as public contributions to public debate about matters of public concern. Beade also takes it that they clearly constitute a public wrong, as an instance of "incitement to hatred", of a kind that we therefore have reason to criminalize (2020: 232): but that is a bit quick. To argue, as Mr Lamb does, that the legal age of sexual consent (which we must suppose is specified in his polity as something over sixteen) is "an atrocity" does not look like incitement to crime, especially since he talks only of consensual intercourse in that context: it is an overdramatically rhetorical way of arguing that the law ought to be changed. His remarks about women who "need to be raped", and about the "rights of women" are more clearly wrong, as expressing unacceptable moral views: they might or might not constitute an offence of "incitement" in English or American law, for instance (we would need to inquire more closely both into his intentions and into the likely effects of his words) but they might amount to an offence in German law (to which Beade appeals), as "assault[ing] the human dignity of others". ${ }^{35}$ Let us agree, however, that we can frame the example so that Mr Lamb's remarks clearly constitute a public wrong: they are, that is, wrongful in a way that properly concerns his fellow citizens, in virtue of their impact on or their implications for the polity's civil order.

If remarks of this kind constitute a public wrong, we therefore have on my account good reason to criminalise them. However, this is not yet to say that they should be criminalized, all things considered: for although we have reason to criminalize them, we must ask whether we should criminalize them rather than responding in one of the various other ways that are available to us, including doing nothing formal or legal, and relying solely on informal kinds of social response to do justice to the wrong (see Duff 2018: ch. 7.2). I won't discuss most of the other possibilities here,$^{36}$ but should say something about the significance of the kinds of informal social response that Mr Lamb suffered-or more precisely, since we are talking so far about whether to criminalize this kind of conduct, rather than about whether to prosecute Mr Lamb in particular, about the kinds of informal response that those who commit this kind of wrong are likely to suffer. The central question is this: should we see such responses as informal, not centrally organized, versions of the kind of response that is formally, publicly, provided by a criminal prosecution; or as something quite different? If the former, we must ask whether we should criminalize as

35 See German Criminal Code (Strafgesetzbuch) \$ 130(1).1; Beade 2020: 232, n. 14; for English and American law, see Ormerod and Laird 2018: 474-94; LaFave 2017: ch. 11.1.

36 But see in particular Beade's comments on why a "restorative justice" response might not be appropriate (Beade 2020: 229-30). 
something additional to such informal responses (for instance because they are thought not to be adequate); or as a formal replacement for such responses, perhaps because they are liable to be misdirected or excessive. If the latter, then it is not clear why the likelihood of such informal responses should be relevant to the question of criminalization.

I am not quite sure how Beade would answer these questions. He talks of the informal responses as species of "public blame", which itself is "the foundation on which a certain type of retributive-communicative punishment is based" (Beade 2020: 224): this implies that a criminal prosecution would provide a formal, perhaps more serious or more proportionate, version of roughly the same kind of censorial response. On the other hand, he also talks of "public humiliation", and of "lynching' in the mass media" (2020: 224), which seem rather different. I would myself say that blame (blaming another to his face) is a mode of calling to account: that is how it can provide the basis for "retributive-communicative punishment", and for criminal prosecution as a formal mode of calling to public account; and such a calling to account is an appropriate response to the wrongdoing of others whom we are still to see and address as responsible fellow members of our normative community (of, in this case, the polity). But public humiliation and media "lynching" are not modes of calling to account; they are therefore not species of public blame (at least of the kind that criminal prosecution formalizes, or of the kind that is appropriate between citizens).

However, whatever we should say about public humiliation or media lynching, there are clearly informal modes of calling to censorial public account that wrongdoers like Mr Lamb might face; these are indeed a feature of a number of recent social and political campaigns, part of whose aim is to "call out", or to call to properly public account, those who commit various kinds of wrong that have not hitherto been taken seriously enough. The question of criminalization is then in part the question of whether such informal callings to account can be expected to be adequately reliable and proportionate; if they cannot, that gives us good (which is not yet to say conclusive) reason to criminalize-both to ensure that an appropriate response is available and, perhaps, to pre-empt the possibility of dangerously disorganized and excessive informal responses. ${ }^{37}$

If we turn now from the question of whether we should criminalize conduct of the type in which Mr Lamb engages, to the question of whether he should be prosecuted, similar issues will arise. In England, for instance, the prosecutor would need to decide not only whether she could lead

37 Compare the idea that a system of formal criminal punishment can serve, in part, to pre-empt vigilante attempts at retribution or revenge: see e.g. Gardner 1998. 
evidence at his trial that would give a reasonable prospect of conviction, but also whether it would be "in the public interest" to prosecute him; even in jurisdictions in which prosecutors are supposedly bound by a "legality principle" that requires them to prosecute if there is sufficient evidence of the person's guilt, they actually have a considerable degree of discretion as to whether to prosecute (or investigate) in individual cases. ${ }^{38}$ I think Beade and I roughly agree on the kinds of consideration to which prosecutors should attend (and to which legislators should attend in deciding whether to criminalize such conduct in the first place): the importance of calling to formal public account those who commit public wrongs-which requires that the calling be done by some person or body who can properly claim to speak for the polity (something that the often self-appointed leaders of informal responses might claim, but not with reliable authority); and how and why this is owed to the wrongdoer as well as to the victim(s). As Beade rightly emphasizes, it follows that wrongdoers have a categorical but nonabsolute right to be prosecuted: that is, not only a right to be prosecuted rather than being subjected to other kinds of legal coercion that may fail to treat them as responsible agents, but a right to be prosecuted rather than having their wrongdoing ignored. To put the point simply, if we are to treat each other as responsible fellow members of a normative community (of, in this case, a polity), we must be ready and willing to, inter alia, call each other to account for the wrongs that we commit against each other.

I want to focus here, however, on a question that Beade addresses only briefly: does the offender also have an "obligation", as Beade puts it, to explain himself-to answer for his conduct, or to provide an account of that conduct. Beade is sure that we should not assert any such obligation: "[w] e cannot claim that a polity may demand an explanation, nor therefore maintain that the wrongdoer is under an obligation to explain himself" (Beade 2020: 228). But this is, I think, much too quick.

If we focus first, as Beade appears to focus, on whether defendants should have a legal obligation to account for themselves, we need to be clear that to impose a legal obligation is not to "force" the person to answer (Beade 2020: 228) —unless the sanction for not answering is really drastic; ${ }^{39}$ even if a failure to discharge such an obligation rendered the person liable not merely to formal censure, but to punishment, that need not amount to forcing them. We should also distinguish different obligations that might

38 On the two tests that English prosecutors must apply, see Ashworth and Redmayne 2010: 194-214; on the legality principle and its actual operation, see e.g. Perrodet 2002, Boyne 2017; see further Duff 2018: 45-9.

39 Defendants in English trials used to be forced to enter a plea, since anyone who refused to do so was subjected to the "peine forte et dure" to coerce a plea (see McKenzie 2005); but a legal obligation need not be thus coercive. 
figure here: for instance, an obligation to appear for trial when summoned; an obligation to enter a formal plea of "Guilty" or "Not Guilty" (and, separately, an obligation to plead honestly); and an obligation not merely to answer formally to the charge by entering a plea, but to engage in the trial and to answer or account for one's conduct. ${ }^{40}$ Thus in English law, for instance, defendants do have a legal obligation to appear for trial, and can be arrested and brought (forcibly) to court if they fail to do so; ${ }^{41}$ they are asked, but are not legally required, to enter a plea (if a defendant refuses to plead, a plea of "Not Guilty" is entered on his or her behalf); and they are not legally required to play any part in the trial, or to offer any account of their actions - though exercising such a right of silence might of course have consequences, if it involves failing to alert the court to a possible defence. Now I do not myself find the first of these legal obligations, to appear for trial, normatively worrying (assuming, of course, a tolerably just criminal process as part of a tolerably just system of criminal law, and a non-oppressive police force), but I do agree with Beade that defendants should not be legally obligated either to enter a plea or to answer for their conduct, on pain of further sanctions if they refuse to do so-essentially for the reason that he gives, that if defendants are to be treated as responsible agents, they must retain the legal right to refuse to answer to the charge, and to refuse to account for themselves. A rebel or dissident who rejects the authority of the court, and who regards his trial as an oppressive travesty, will not be able to avoid being tried (the law cannot allow dissent to bar the trial): but he should be allowed, without further penal consequences, to make clear his denial of the court's authority by refusing to play any active part in the process.

However, it does not follow from this that the polity may not "demand an explanation"; nor that we cannot say that a defendant has a civic, as opposed to a legal, responsibility or obligation to enter a plea and to answer for his conduct in the trial. Civic obligations lack the formal force of law: they are nothing more (or less) than aspects of what we hope is a shared understanding of what it is to be a citizen, of what we owe to each other as citizens; they are enforceable only by informal persuasion from our fellow citizens; but they are crucial aspects of civic life-there would be something sadly amiss with a polity whose members recognized only legal obligations or responsibilities towards each other. If we are to ask whether those who have committed criminal wrongs, or those who are accused on reasonable grounds of committing such wrongs, have a civic obligation or responsibility

40 My comments here apply to "adversarial" trials; the account would need to be adjusted for trials in more "inquisitorial" systems.

41 At least for trials "on indictment”, for more serious offences; see Bail Act 1976, s. 7. 
to answer such accusations, and to answer for their conduct, in a criminal trial, the answer must surely be that they do-assuming, again, a tolerably just system of criminal justice, which addresses them properly as members of the polity.

The justification for this answer is that if I am a citizen of the polity whose criminal law I am accused of violating, I have a civic responsibility to assist the criminal law's enterprise, including the enterprise of calling criminal wrongdoers to public account: if I know that I am a criminal wrongdoer, I must recognize my crime as a public wrong, for which I should now answer, to my fellow citizens, whose business it is; and the criminal trial is the public forum in which criminal wrongdoers are formally called to answer. I must therefore be ready to face trial-and indeed, if I know that I am guilty, to plead guilty at my trial. Even if I believe (or know) that I am innocent, I have a responsibility to answer to the accusation, to explain why I am not guilty - and to offer evidence to back that explanation up: for I must recognise that the enterprise of calling public wrongdoers to censorial account requires a practice of calling alleged public wrongdoers to account, in order to establish whether they are guilty or not; and as a citizen whose law this is, I have a responsibility to assist in that enterprise, and to answer to my fellow citizens if I am accused (on reasonable grounds) of committing a public wrong. This is one of the ways in which citizens of a democratic republic should see themselves not merely as subject to its law, but as agents of the law-as active participants in the enterprise of democratic self-governance.

However, I should emphasize that this civic responsibility to participate in my criminal trial ought not (for the reasons indicated above) be turned into a sanction-backed legal duty; a citizen must retain the legal right to refuse to take part in the process. I should also emphasize that citizens can have such a civic responsibility only in a polity and a criminal justice system that is tolerably just: one that treats them as equal members of the political community, with the respect and concern that is therefore due to them; one that imposes humane, proportionate punishments on convicted offenders; and one whose criminal process enables those accused of crimes to answer for themselves as responsible citizens. I leave it to readers to ask how far our existing systems of criminal law meet these conditions.

\section{CONCLUDING REMARK}

I am painfully aware of at least some of the flaws in my book: in particular of the number of questions that it leaves unanswered, of various ways in which its arguments are under-developed or unclear, of how much work 
remains to be done to articulate more adequately and persuasively a normative understanding of criminal law as helping to sustain and to constitute a polity's civil order, by providing an appropriate response to wrongs that violate that order. My commentators here have highlighted some of those flaws: but I hope that in my response I have shown that they have not cast doubt on the central features of this account of criminal law.

\section{BIBLIOGRAPHY}

Ashworth, A. J., and Redmayne, M., 2010: The Criminal Process (4th ed.), Oxford: Oxford University Press

Beade, G., 2020: "Should Public Blame Replace the Criminal Trial?" Law, Ethics and Philosophy 7: 222-233.

Boyne, S., 2017: “German Prosecutors and the Rechtsstaat”, in Prosecutors and Democracy, ed. M. Langer and D. Sklansky, 138-74, Cambridge: Cambridge University Press

Brownlee, K., 2020: "Professional Ethics and Criminal Law" Law, Ethics and Philosophy 7: 174-190.

Chiao, V., 2019: Criminal Law in the Age of the Administrative State, New York, Oxford University Press

Dempsey, M. M., 2009: Prosecuting Domestic Violence: A Philosophical Analysis, Oxford: Oxford University Press

-2011: “Public Wrongs and the 'Criminal Law's Business': When Victims Won't Share”, in Crime, Punishment, and Responsibility, ed. R Cruft et al, 254-72, Oxford: Oxford University Press

-2020: "The Public Realms: On How to Think About Public Wrongs" Law, Ethics and Philosophy 7: 158-173.

Duff, R. A., 2001: Punishment, Communication, and Community, New York: Oxford University Press

-2013: "Relational Reasons and the Criminal Law", Oxford Studies in Legal Philosophy 2: 175-208.

-2018: The Realm of Criminal Law, Oxford: Oxford University Press

Duff, R. A., and Marshall, S. E., 2016: "Civic Punishment", in Democratic Theory and Mass Incarceration, ed. A. Dzur et al, 33-59, Oxford: Oxford University Press

Duff, R. A, Farmer, L., Marshall, S. E., Renzo, M., and Tadros, V., 2014: "Introduction: Towards a Theory of Criminalization?", in Criminalization: The Political Morality of the Criminal Law, ed. R. A. Duff et al, 1-53, Oxford: Oxford University Press

Dworkin, R. M., 1986: Law's Empire, London: Fontana

Farmer, L., 2016: Making the Modern Criminal Law: Criminalization and Civil Order, Oxford: Oxford University Press

Gardner, J., 1998: “Crime: in Proportion and in Perspective”, in Fundamentals of Sentencing Theory, ed. A. J. Ashworth and M. Wasik, 31-52, Oxford: Oxford University Press

-2007: "Complicity and Causality", in Gardner, Offences and Defences, 57-76, Oxford: Oxford University Press 
-2011: "Relations of Responsibility", in Crime, Punishment, and Responsibility, ed. R Cruft et al, 87-102, Oxford: Oxford University Press

Gargarella, R., 2020: "Democratic Dialogue, Multiculturalism, and 'Public Wrongs'” Law, Ethics and Philosophy 7: 191-208.

Hörnle, T., 2020: “One Master Principle of Criminalization-Or Several Principles?” Law, Ethics and Philosophy 7: 209-221.

Jones, I., 2017: “A Grave Offence: Corpse Desecration and the Criminal Law", Legal Studies 37: 599-620

LaFave, W., 2017: Criminal Law (6th ed.), St Paul MN: West Academic Publishing

McKenzie, A., 2005: “This Death Some Strong and Stout Hearted Man Doth Choose", Law and History Review 23: 279-313.

Moore, M. S., 1997: Placing Blame: A Theory of Criminal Law, Oxford: Oxford University Press

Nagel, T., 1986: The View from Nowhere, New York: Oxford University Press

Ormerod, D., and Laird. K., 2018: Smith and Hogan's Criminal Law (15th ed.), Oxford: Oxford University Press

Perrodet, A., 2002: “The Public Prosecutor", in European Criminal Procedures, ed. M. Delmas-Marty and J. R. Spencer, 415-58, Cambridge: Cambridge University Press

Simester, A. P., and Sullivan, G. R., 2005: “On the Nature and Rationale of Property Offences", in Defining Crimes: Essays on the Special Part of the Criminal Law, ed. R. A. Duff and S. P. Green, 168-95, Oxford: Oxford University Press

Thorburn, M., 2010: "Criminal Law as Public Law", in Philosophical Foundations of Criminal Law, ed. R. A. Duff and S. P. Green, 21-43, Oxford: Oxford University Press

Wenar, L., 2013: “The Nature of Claim-Rights”, Ethics 123: 202-29. 